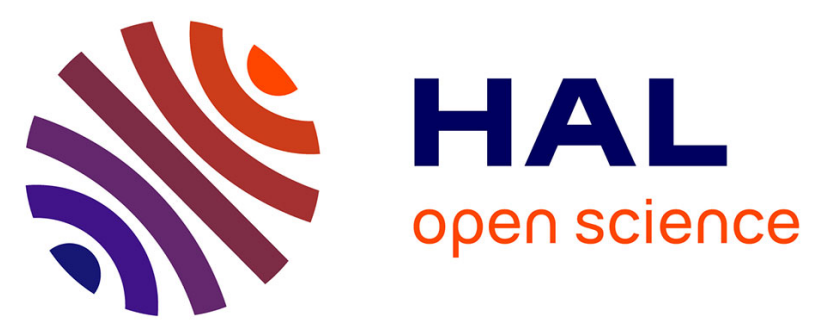

\title{
The two mutations, Q204X and nt821, of the myostatin gene affect carcass and meat quality in young heterozygous bulls of French beef breeds
}

Sophie Allais, Hubert H. Levéziel, Nathalie Payet-Duprat, Jean-François J.-F. Hocquette, Jacques Lepetit, Sylvie Rousset, Christophe Denoyelle, Carine

Bernard-Capel, L. Journaux, Aline Bonnot, et al.

\section{To cite this version:}

Sophie Allais, Hubert H. Levéziel, Nathalie Payet-Duprat, Jean-François J.-F. Hocquette, Jacques Lepetit, et al.. The two mutations, Q204X and nt821, of the myostatin gene affect carcass and meat quality in young heterozygous bulls of French beef breeds. Journal of Animal Science, 2010, 88 (2), pp.446-454. 10.2527/jas.2009-2385 . hal-01193527

\section{HAL Id: hal-01193527 \\ https://hal.science/hal-01193527}

Submitted on 31 May 2020

HAL is a multi-disciplinary open access archive for the deposit and dissemination of scientific research documents, whether they are published or not. The documents may come from teaching and research institutions in France or abroad, or from public or private research centers.
L'archive ouverte pluridisciplinaire HAL, est destinée au dépôt et à la diffusion de documents scientifiques de niveau recherche, publiés ou non, émanant des établissements d'enseignement et de recherche français ou étrangers, des laboratoires publics ou privés. 


\section{JOURNAL OF ANIMAL SCIENCE}

The Premier Journal and Leading Source of New Knowledge and Perspective in Animal Science

The two mutations, Q204X and nt821, of the myostatin gene affect carcass and meat quality in young heterozygous bulls of French beef breeds

S. Allais, H. Levéziel, N. Payet-Duprat, J. F. Hocquette, J. Lepetit, S. Rousset, C. Denoyelle, C. Bernard-Capel, L. Journaux, A. Bonnot and G. Renand

J ANIM SCI 2010, 88:446-454.

doi: 10.2527/jas.2009-2385 originally published online December 4, 2009

The online version of this article, along with updated information and services, is located on the World Wide Web at:

http://www.journalofanimalscience.org/content/88/2/446

WWw.asas.org 


\title{
The two mutations, Q204X and nt821, of the myostatin gene affect carcass and meat quality in young heterozygous bulls of French beef breeds ${ }^{1}$
}

\author{
S. Allais ${ }^{* \dagger^{2}}$ H. Levéziel,$\ddagger \oint$ N. Payet-Duprat, $₫ \oint$ J. F. Hocquette,\# J. Lepetit, \\ S. Rousset, C. Denoyelle, ${ }^{* *}$ C. Bernard-Capel, ** L. Journaux, $\dagger$ \\ A. Bonnot, $* *$ and G. Renand*
}

*INRA, UMR 1313 Unité de Génétique Animale et Biologie Intégrative, F-78350 Jouy en Josas, France; †Union Nationale des Coopératives agricoles d'Elevage et d'Insémination Animale, F-75595 Paris Cedex 12, France; łINRA, UMR 1061 Unité de Génétique Moléculaire Animale, F-87060 Limoges, France; §Université de Limoges, UMR 1061 Unité de Génétique Moléculaire Animale, F-87060 Limoges, France; \#INRA, UR 1213 Unité de Recherche sur les Herbivores, F-63122 Saint Genès Champanelle, France; ||INRA, UR 370 Unité Qualité des Produits Animaux, F-63122 Saint Genès Champanelle, France; qINRA, UMR 1019 Unité de Nutrition Humaine, Centre de Recherches en Nutrition Humaine d'Auvergne, F-63001 Clermont-Ferrand, France; and **Institut de l'Elevage, F-75595 Paris Cedex 12, France

\begin{abstract}
The availability of genetic tests to detect different mutations in the myostatin gene allows the identification of heterozygous animals and would warrant the superiority of these animals for slaughter performance if this superiority is confirmed. Thus, 2 mutations of this gene, Q204X and nt821, were studied in 3 French beef breeds in the program Qualvigène. This work was done with 1,114 Charolais, 1,254 Limousin, and 981 Blonde d'Aquitaine young bulls from, respectively, 48, 36, and 30 sires and slaughtered from 2004 to 2006. In addition to the usual carcass traits recorded at slaughter (e.g., carcass yield, muscle score), carcass composition was estimated by weighing internal fat and dissecting the 6 th rib. The muscle characteristic traits analyzed were lipid and collagen contents, muscle fiber section area, and $\mathrm{pH}$. Regarding meat quality, sensory qualities of meat samples were evaluated by a taste panel, and Warner-Bratzler shear force was measured. Deoxyribonucleic acid was extracted from the blood samples of all calves, the blood samples of $78 \%$ of the dams, and the blood or semen samples of all the sires. Genotypes were determined for 2 disruptive
\end{abstract}

mutations, Q204X and nt821. Analyses were conducted by breed. The superiority of carcass traits of calves carrying one copy of the mutated allele (Q204X or nt821) over noncarrier animals was approximately $+1 \mathrm{SD}$ in the Charolais and Limousin breeds but was not significant in the Blonde d'Aquitaine. In the Charolais breed, for which the frequency was the greatest (7\%), young bulls carrying the Q204X mutation presented a carcass with less fat, less intramuscular fat and collagen contents, and a clearer and more tender meat than those of homozygous-normal cattle. The meat of these animals also had slightly less flavor. Also in the Charolais breed, 13 of 48 sires were heterozygous. For each sire, the substitution effect of the wild allele by the mutant allele was approximately +1 SD for carcass conformation and yield, showing that the estimate of the substitution effect was independent of family structure, as it ought to be for a causal mutation. These results illustrate the challenge of using genetic tests to detect animals with the genetic potential for greater grades of carcasses and meat quality.

Key words: beef cattle, carcass trait, $G D F 8$, meat quality, myostatin, polymorphism

(C)2010 American Society of Animal Science. All rights reserved.

J. Anim. Sci. 2010. 88:446-454 doi:10.2527/jas.2009-2385

\footnotetext{
${ }^{1}$ This work was supported by the Agence Nationale de la Recherche (Paris, France; contract numbers 05-GANI-017-04, ANRGANI-017, ANR-06-GANI-001), Apis-Gène (Paris, France), the Office de l'Elevage (Montreuil sous Bois, France), and the FNE (Fonds National de l'Elevage, Paris, France). The authors thank the AI enterprise partners of the Qualvigène project: Gene Diffusion (Douai, France), Midatest (Soual, France), UALC (Union Auvergne Limousin Charente, Naves, France), and UCATRC (Union des Coo-
}

pératives Associées pour le Testage de la Race Charolaise, Lempdes, France); the enterprise Labogena (Jouy en Josas, France) for SNP genotyping; and all the technicians from feedlots, slaughterhouses, and biology laboratories of INRA and Institut de l'Elevage.

${ }^{2}$ Corresponding author: sophie.allais@jouy.inra.fr

Received August 10, 2009.

Accepted October 29, 2009. 


\section{INTRODUCTION}

The GDF8 gene has been identified as the gene responsible for the muscle hypertrophy ( $\mathbf{m h}$ ) phenotype, or double-muscling, in cattle (Grobet et al., 1997; McPherron and Lee, 1997). It has been mapped to the centrometric end of chromosome 2 in cattle (Charlier et al., 1995; Dunner et al., 1997; Smith et al., 1997). The expression of the gene results in the production of myostatin, a protein that suppresses both the proliferation and differentiation of myogenic cells (Grobet et al., 1997). Several mutations in the gene (e.g., nt821, Q204X, C313Y) were shown to be involved in the production of a disrupted myostatin, which leads to an increase in muscle mass in the animals carrying 2 copies of inactive alleles (Kambadur et al., 1997; Grobet et al., 1998).

In addition to adverse effects on fitness (dystocia, stress susceptibility, fertility), the beef value of homozygous double-muscled cattle is well documented: a dramatic increase in saleable meat yield as a consequence of improved dressing percentage (reduced digestive tract), reduced carcass fatness, and fineness of the limb bones (for reviews, see Ménissier, 1982b; Arthur, 1995). The beef value of the heterozygous cattle was first estimated in experiments in which the homozygosity of the parent genotypes was inferred from visual phenotypes. However, it was often difficult to distinguish the heterozygote from the homozygote-normal cattle, leading to the hypothesis that the mh gene was partially recessive (Ménissier, 1982c). The availability of molecular tests then enabled researchers to distinguish genotypes unequivocally.

In breeds in which myostatin mutated alleles are segregating, there is a need to know the current frequency of mh genotypes and the actual beef value superiority of the heterozygous cattle over noncarrier cattle to help breeders make rational decisions about the mh breeding strategy. The objectives of this study were to take advantage of an informative French testing design to determine 1) the frequencies of the Q204X and nt821 disruptive mutations in the Charolais, Limousin, and Blonde d'Aquitaine breeds, and 2) the effect of 1 single copy of the inactive allele on carcass traits, muscle characteristics, and meat quality.

\section{MATERIALS AND METHODS}

Animals used in this study were slaughtered in accredited slaughterhouses according to the protection of animals rules defined in the French law (Code Rural, articles R214-64 to R214-71, http://www.legifrance. gouv.fr).

In a collaboration between AI enterprises, INRA, and Institut de l'Elevage, a research program named Qualvigène was implemented to study the genetic determinism of beef and meat quality traits. This study was fully integrated in the Qualvigène program.

\section{Animals}

The Qualvigène program was based on 3 successive years of progeny tests. Purebred young bulls, progeny of 48 Charolais, 36 Limousin, and 30 Blonde d'Aquitaine sires, were randomly procreated in a large number of herds from mostly unrelated dams. In each breed and each year, calves were born within a restricted period of 17 wk. After weaning on the farm of origin, bull calves entered the feedlots at 40,37 , or 24 wk of age on average $( \pm 3 \mathrm{wk})$ for the 3 respective breeds. The Charolais bull calves were fattened in 2 locations and fed ad libitum with whole-plant corn silage. The Limousin bull calves were fattened in a single feedlot and fed ad libitum with wet corn silage. The Blonde d'Aquitaine bull calves were fattened in a single feedlot with a dried corn diet. The young bulls were shipped to slaughterhouses without mixing animals from different fattening lots and in accordance with good animal transport practices. They were humanely slaughtered in commercial slaughterhouses (a single slaughterhouse for each feedlot) when they reached $730( \pm 15) \mathrm{kg}$ of BW on average for the Charolais progeny and $479( \pm 3)$ or $417( \pm 4)$ $\mathrm{d}$ on average for the Limousin or Blonde d'Aquitaine progeny, respectively. After editing, the records of 10 animals were discarded from the database because of sanitary problems, penalized growth during fattening, or both, and 6 others were discarded for genotype incompatibility with the sire. A total of 1,114 Charolais, 1,254 Limousin, and 981 Blonde d'Aquitaine purebred young bulls were eventually used in this study.

\section{Traits Analyzed}

The traits usually recorded in the progeny tests were birth weight $(\mathrm{kg})$, ADG during fattening $(\mathrm{kg} / \mathrm{d})$, age (d), and BW (kg) at the end of fattening. At slaughter, the $\mathrm{HCW}(\mathrm{kg})$, without trimming, was recorded and carcass yield (\%) was calculated. The next day, the chilled carcass was graded by a technician from the Institut de l'Elevage in accordance with the European Union beef carcass classification system adapted from the European Association for Animal Production reference methods defined by De Boer et al. (1974). Muscularity was assessed across 6 classes (SEUROP classification, where $\mathrm{S}$ is the highest score and $\mathrm{P}$ the least), and fatness across 5 classes (1 to 5 ). Each class was subdivided into minus $(-)$, equals $(=)$, and plus $(+)$ subclasses. Scores were recoded to numeric variables: muscle score (scale of 1 to 18 , where 1 is poorly muscled and 18 is heavily muscled); fatness score (scale of 1 to 15 , where 1 is extremely lean and 15 is extremely fat). Eventually, the length of the leg $(\mathrm{cm})$ and the maximum width of the thigh $(\mathrm{cm})$ were measured according to the recommendations of De Boer et al. (1974).

In addition to these routinely recorded traits, other measurements were specifically recorded for this study. Internal (pelvic and kidney) fat was removed from the warm carcass and weighed $(\mathrm{kg})$. The decrease in tem- 
perature during chilling was monitored with captors inserted in the carcass between the 10th and 11th rib of 2 or 3 one-half carcasses per slaughter batch (13 to 26 young bulls slaughtered per batch on average for the 3 breeds). The next day, a 4-rib section (approximately $20 \mathrm{~cm}$ from the 6th to 9 th rib) was removed from the right half carcass. The 6 th rib was separated and immediately frozen. The longissimus thoracis (LT) muscle was excised from the 7th to 9th ribs, sliced into 3 steaks. The first one was divided into small samples and immediately frozen for later analyses. The 2 others were vacuum-packaged and kept at $4^{\circ} \mathrm{C}$ for $14 \mathrm{~d}$ for aging before to be frozen.

After thawing, the $\mathrm{pH}$ and the rib eye area $\left(\mathrm{cm}^{2}\right)$ were measured on the 6 th rib. The rib was then dissected into muscle, fat, and bone. The rib fat content (\%) was calculated as the ratio of dissected fat (intermuscular + subcutaneous) to the weight of muscle + fat. The lightness $\left(\mathrm{L}^{*}\right)$ was measured on the freshly cut LT muscle section using a Minolta spectrophotometer (CM 2002, Minolta France SA, Carrières sur Seine, France). Muscle characteristics were measured on the 7th-rib LT steak. Intramuscular lipid content was measured by the Soxhlet method using a Soxtherm apparatus (Gerhardt France SARL, Les Essarts Le Roi, France). Insoluble collagen content (\%) was measured on a LT muscle sample after $2 \mathrm{~h}$ of heat treatment in a buffer solution at $90^{\circ} \mathrm{C}$. This was estimated from the measurement of hydroxyproline content (collagen $=7.5 \times$ hydroxyproline) according to the method of Bergman and Loxley (1963) modified by Bonnet and Kopp (1984). Muscle fiber section mean area $\left(\mu \mathrm{m}^{2}\right)$ was determined on $10-\mu \mathrm{m}-$ thick sections cut perpendicularly to the muscle fibers with a cryotome at $-25^{\circ} \mathrm{C}$. Between 100 and 200 fibers of 2 samples per muscle were measured to calculate the mean fiber section area by computerized image analysis. The ratio of rib eye area to the mean fiber section area was calculated as a rough and approximate estimate of hyperplasia in LT muscle. The 8th-rib LT steaks were thawed and then cooked over an electric grill to an internal temperature of $55^{\circ} \mathrm{C}$ (rare cooking), using a standardized cooking temperature, cooking time, and cooking equipment. Cooked steaks were cooled to room temperature before 10 parallelepiped core samples were cut with the fiber orientation parallel to the long axis. The Warner-Bratzler shear force $\left(\mathrm{N} / \mathrm{cm}^{2}\right)$ was averaged on the 10 core measures. The sensory quality attributes were evaluated by 3 test panels ( 1 for each breed) composed of 12 trained panelists. Within each panel, most of the panelists remained over the $3 \mathrm{yr}$. The same cooking procedure as above was applied on the 9th-rib LT steaks, and the cooked steaks were immediately served to panelists. The Limousin and Blonde d'Aquitaine test panels had to evaluate 12 samples in each session, and the Charolais test panel had to evaluate 15 samples. Panelists scored tenderness, juiciness, and flavor on nonstructured 100-point scales: from 1 (extremely tough, dry or weak) to 100 (extremely tender, juicy or intense). The scores were averaged over the scores of each panelist for each animal.

\section{SNP Genotyping}

Deoxyribonucleic acid was extracted from blood samples $(1 \mathrm{~mL})$ for all calves, blood samples $(1 \mathrm{~mL})$ for $78 \%$ of the dams, and blood $(1 \mathrm{~mL})$ or semen samples $(0.22$ to $0.25 \mathrm{~mL})$ for all the sires. Genotypes were determined for 2 disruptive mutations (Q204X and nt821) of the $G D F 8$ gene, which is located on the centrometric end of the bovine chromosome 2. The first mutation, $\mathrm{Q} 204 \mathrm{X}$, is a $\mathrm{C} \rightarrow \mathrm{T}$ substitution at nucleotide position 610 in the second exon, generating a premature stop codon in the N-terminal latency-associated peptide at AA position 204. The second mutation, nt821, is a deletion of $11 \mathrm{bp}$ at nucleotide position 821 in the third exon, producing a premature stop codon (Grobet et al., 1998). The Q204X genotyping was performed using TaqMan SNP genotyping assays designed by Applied Biosystems (Courtaboeuf, France; forward primer: 5'-GGAATCCGATCTCTGAAACTTGACA-3'; reverse primer: 5'-GCTCTGCAACACTGTCTTCAC-3'; discriminantly labeled probes: CAATGCTCTGCCAAATA and ATCAATGCTCTACCAAATA) with an ABI 7900HT Real-Time PCR System (Applied Biosystems). The nt821 deletion was genotyped by amplicon size determination on an ABI 3100 genetic analyzer (Applied Biosystems); PCR products were obtained using a labeled forward primer (5'-TCTTCTTTCCTTTCCATACA-3') and an unlabeled reverse primer (5'-ACATCTTTGTAGGAGTACAGC-3').

\section{Statistical Analysis}

Analyses were conducted by breed. Data were analyzed by a mixed-model ANOVA with the MIXED procedure (SAS Inst., Inc., Cary, NC). The first analytical model was $\mathrm{Y}_{\mathrm{ijkl}}=\mu+\mathrm{C}_{\mathrm{i}}+\mathrm{G}_{\mathrm{j}}+\mathrm{S}_{\mathrm{k}}+\mathrm{e}_{\mathrm{ijkl}}$, where $Y_{\mathrm{ijkl}}$ are phenotypic observations, $\mu$ is the overall mean, $\mathrm{C}_{\mathrm{i}}$ is the fixed effect of contemporary group (i.e., the cattle from the same fattening lot and slaughtered the same day) or the date of taste panel for the sensory quality traits, $G_{j}$ is the fixed effect of genotypes, $S_{k}$ is the random effect of sire, and $e_{\mathrm{ijkl}}$ is random error. In this model, the substitution effect was estimated at the population level directly by the contrast between the effects of the genotypes $(\mathrm{mh} /+)$ and $(+/+)$ and the associated probability value (DIFF option of the least squares means procedures of SAS).

To estimate the substitution effect between the mutated and normal allele within heterozygous sires, a second model was fitted: $\mathrm{Y}_{\mathrm{ijkl}}=\mu+\mathrm{C}_{\mathrm{i}}+\mathrm{S}_{\mathrm{k}}+\mathrm{A}(\mathrm{S})_{\mathrm{kj}}+$ $\mathrm{e}_{\mathrm{ijk} k}$, where $\mathrm{Y}_{\mathrm{ijkl}}, \mu, \mathrm{C}_{\mathrm{i}}, \mathrm{S}_{\mathrm{k}}$, and $\mathrm{e}_{\mathrm{ijkl}}$ have the same definition as in the first model. The effect $\mathrm{A}(\mathrm{S})_{\mathrm{kj}}$ refers to the effect of the transmitted allele $A_{j}$ within sire $S_{k}$. This model could be used only in the Charolais breed, for which the within-sire substitution effects were estimat- 
Table 1. Number of sire, dam, and progeny genotypes in the 3 breeds and the corresponding frequency within each category of animals and breed

\begin{tabular}{lccc}
\hline \hline Genotype & Charolais & Limousin & Blonde d'Aquitaine \\
\hline Sire & & & \\
+/+ & $35(73 \%)$ & $35(97 \%)$ & $30(100 \%)$ \\
+/Q204X & $13(27 \%)$ & $0(0 \%)$ & $0(0 \%)$ \\
+/nt821 & $0(0 \%)$ & $1(2.8 \%)$ & $0(0 \%)$ \\
Dam & & & $616(97 \%)$ \\
+/+ & $748(87 \%)$ & $919(94 \%)$ & $8(1.3 \%)$ \\
+/Q204X & $115(13 \%)$ & $14(1.4 \%)$ & $8(1.3 \%)$ \\
+/nt821 & $1(0.1 \%)$ & $43(4.4 \%)$ & $949(99 \%)$ \\
Progeny & & & $5(0.5 \%)$ \\
+/+ & $901(82 \%)$ & $1,208(97 \%)$ & $5(0.5 \%)$ \\
+/Q204X & $191(17 \%)$ & $8(0.6 \%)$ & \\
+/nt821 & $1(0.1 \%)$ & $34(2.7 \%)$ & \\
\hline
\end{tabular}

ed as the contrasts between performances of progeny that unequivocally received the mutated allele from the sire and performances of normal homozygous progeny from this sire.

\section{RESULTS}

\section{Genotypic and Allelic Frequencies}

The frequencies in each breed of heterozygous animals for the Q204X and nt821 mutations are reported in Table 1. No animal carrying 2 copies of inactive alleles of the myostatin gene could be found in any genotyped cattle in this study. Even in the Charolais breed, mutated homozygous animals were absent although the apparent allele frequency of the Q204X mutation would be compatible with a frequency $0.5 \%$ of $\mathrm{mh}$ homozygous animals (i.e., approximately 5 homozygous calves). The reasons for this absence were that 1 ) the AI enterprises never progeny test double-muscled sires for pure breeding; 2) the AI enterprises never use double-muscled dams as support for procreating test progeny; and 3) even if a double-muscled progeny were born by chance from 2 heterozygous parents, it would never enter the fattening station because it would be considered too extreme and too fragile. An unbiased estimate of the mutated allele frequency $(\mathbf{p})$ in the 3 breeds could, however, be calculated from the observed frequency (h) of heterozygous dams, given that dams were a representative sample of each breed, except that there was no double-muscled female (homozygous mh/ $\mathrm{mh})$ in this sample: $\mathrm{p}=\mathrm{h} /(2-\mathrm{h})$.

The Q204X mutation was present predominantly in the Charolais breed, with $\mathrm{h}=13 \%$ of the dams being heterozygous. Less than $\mathrm{h}=2 \%$ of the dams in the 2 other breeds were heterozygous. Consequently, the frequency of the Q204X allele could be estimated as $\mathrm{p}=$ $7 \%$ in the Charolais breed and $\mathrm{p}=$ less than $1 \%$ in the Limousin and Blonde d'Aquitaine breeds. The nt821 mutation was almost absent in the Charolais breed. In the Limousin breed, there were $\mathrm{h}=4.4 \%$ heterozygous dams, corresponding to a frequency of the nt821 allele of $\mathrm{p}=2 \%$. In the Blonde d'Aquitaine breed, the fre- quency of the inactive nt821 allele was as small as the frequency of the inactive Q204X allele.

In each breed, sires are selected by AI enterprises according to their own selection objectives; therefore, they cannot be representative of the whole population. The proportion of heterozygous sires in the Charolais sample $(27 \%)$ appeared to be greater than the proportion of heterozygous dams, leading to a marked frequency of heterozygous calves (17\%) among the test progeny. Only 1 calf was observed carrying a copy of the nt821 allele in this breed. No heterozygous Blonde d'Aquitaine sire could be found, and a single heterozygous sire was found in the Limousin breed. The numbers of heterozygous progeny were very small in these 2 breeds, 1 and 3\%, respectively.

\section{Substitution Effect of Inactive Alleles of the Myostatin Gene on Carcass Yield and Muscle Score in the 3 Breeds}

Given that the frequencies of the inactive alleles were very small in the Limousin and Blonde d'Aquitaine breeds, the 2 inactive Q204X and nt821 alleles were pooled in the same class, mh. The means and residual SD (RSD) of carcass yield and carcass muscle score are reported in Table 2 for the 3 breeds. The substitution effect of the normal allele by the mh allele at the population level was calculated as the contrast between heterozygous and normal homozygous cattle $[\mathrm{a}=$ $(\mathrm{mh} /+)-(+/+)]$ and the contrast divided by the RSD (Table 2) with the first model. In the Charolais and Limousin breeds, the young heterozygous bulls were 1 SD over homozygous animals for both carcass yield and conformation score $(P<0.001)$. In the Blonde d'Aquitaine breed, the superiority of the heterozygous over homozygous animals was only approximately 0.5 RSD and was not significant for both traits.

\section{Effect of the Mutation Q204X in the Charolais Breed}

The effect of a single copy of a mutated allele on all the recorded traits with the first model was estimated 
Table 2. Number of young bulls, means, and muscle hypertrophy (mh) allele effects $[\mathrm{a}=(\mathrm{mh} /+)-(+/+)]$, with $\mathrm{SE}$, and divided by the phenotypic SD (residual $\left.\mathrm{SD}^{1}\right)$ for carcass yield and carcass muscle score in the 3 breeds, with the corresponding $P$-value

\begin{tabular}{|c|c|c|c|c|c|}
\hline Breed and trait & No. & Mean & $\mathrm{a} \pm \mathrm{SE}$ & $\mathrm{a} / \mathrm{RSD}$ & $P$-value \\
\hline \multicolumn{6}{|l|}{ Charolais } \\
\hline Carcass yield, \% & 1,113 & 57.70 & $1.93 \pm 0.13$ & 1.17 & $<0.001$ \\
\hline Carcass conformation score ${ }^{2}$ & 1,114 & 9.96 & $1.47 \pm 0.12$ & 1.01 & $<0.001$ \\
\hline \multicolumn{6}{|l|}{ Limousin } \\
\hline Carcass yield, $\%$ & 1,254 & 61.96 & $1.68 \pm 0.20$ & 1.30 & $<0.001$ \\
\hline Carcass conformation score ${ }^{2}$ & 1,254 & 10.94 & $1.38 \pm 0.24$ & 0.90 & $<0.001$ \\
\hline \multicolumn{6}{|l|}{ Blonde d'Aquitaine } \\
\hline Carcass yield, \% & 981 & 64.98 & $0.72 \pm 0.46$ & 0.51 & 0.11 \\
\hline Carcass conformation score ${ }^{2}$ & 981 & 10.90 & $0.83 \pm 0.43$ & 0.60 & 0.06 \\
\hline
\end{tabular}

${ }^{1} \mathrm{RSD}=$ root mean square error of the basic model that includes only the fixed effect of the contemporary groups.

${ }^{2}$ Scale of 1 to 18 , where 1 is poorly muscled and 18 is heavily muscled.

only in the Charolais breed, in which the increased frequency of heterozygous animals allowed very accurate estimations. In this Charolais population, only the Q204X mutation was studied because there was only 1 heterozygous animal for the nt821 mutation. This animal was discarded from analysis. The substitution effects at the population level of the normal allele by the inactive Q204X allele on all recorded traits are reported in Table 3 . Heterozygous bull calves were slightly $(+0.17$ RSD), but significantly $(P<0.04)$, heavier at birth than homozygous-normal calves and they showed more difficulty at birth $(+0.37 \mathrm{RSD}, P<0.001)$. Postweaning growth in the feedlot (daily BW gain, slaughter age and $\mathrm{BW}$ ) was not affected by the presence of the inactive myostatin allele.

Similarly to carcass yield and muscle score, the carcasses of heterozygous animals were markedly heavier $(+0.98 \mathrm{RSD})$, the thighs were thicker $(+0.84 \mathrm{RSD})$ and the rib eye areas were larger $(+0.65 \mathrm{RSD})$ than those of young homozygous bulls. On the contrary, their legs were significantly shorter $(-0.32 \mathrm{RSD})$. The carcass composition was very different between heterozygous and homozygous-normal cattle. The heterozygous animals were markedly leaner, with less internal fat $(-0.57$ RSD) and less fat on the 6th rib (-0.84 RSD). Significant differences in muscle characteristics were also

Table 3. Number of young bulls, means, and muscle hypertrophy $(\mathrm{mh})$ allele effects $[\mathrm{a}=(\mathrm{mh} /+)-(+/+)]$, with $\mathrm{SE}$, and divided by the phenotypic SD (residual $\mathrm{SD}^{1}$ ) for growth, carcass, muscle, and meat quality traits in the Charolais breed, with the corresponding $P$-value

\begin{tabular}{|c|c|c|c|c|c|}
\hline Trait & No. & Mean & $\mathrm{a} \pm \mathrm{SE}$ & $\mathrm{a} / \mathrm{RSD}$ & $P$-value \\
\hline Birth weight, $\mathrm{kg}$ & 1,111 & 48.73 & $0.98 \pm 0.48$ & 0.17 & 0.04 \\
\hline Calving difficulty score ${ }^{2}$ & 1,108 & 1.43 & $0.24 \pm 0.05$ & 0.37 & $<0.001$ \\
\hline $\mathrm{ADG}, \mathrm{kg} / \mathrm{d}$ & 1,113 & 1.65 & $12.18 \pm 14.85$ & 0.07 & 0.41 \\
\hline Slaughter age, $\mathrm{d}$ & 1,114 & 500.50 & $2.45 \pm 2.05$ & 0.10 & 0.23 \\
\hline Slaughter weight, kg & 1,113 & 729.99 & $-0.77 \pm 1.06$ & -0.06 & 0.46 \\
\hline $\mathrm{HCW}, \mathrm{kg}$ & 1,114 & 421.47 & $13.17 \pm 1.12$ & 0.98 & $<0.001$ \\
\hline Thigh width, cm & 1,114 & 32.86 & $8.17 \pm 0.83$ & 0.84 & $<0.001$ \\
\hline LM area, $\mathrm{cm}^{2}$ & 1,114 & 53.38 & $548.98 \pm 72.55$ & 0.65 & $<0.001$ \\
\hline Leg length, cm & 1,114 & 87.31 & $-5.95 \pm 1.63$ & -0.32 & $<0.001$ \\
\hline Fatness score ${ }^{3}$ & 1,114 & 8.65 & $-0.20 \pm 0.12$ & -0.14 & 0.11 \\
\hline Internal fat, $\mathrm{kg}$ & 1,107 & 8.74 & $-1.21 \pm 0.18$ & -0.57 & $<0.001$ \\
\hline Rib fat, $\%$ & 1,113 & 20.41 & $-3.06 \pm 0.30$ & -0.84 & $<0.001$ \\
\hline Intramuscular lipids, $\%$ & 1,114 & 1.53 & $-0.47 \pm 0.07$ & -0.56 & $<0.001$ \\
\hline Insoluble collagen, $\%$ & 1,114 & 0.30 & $-0.02 \pm 0.004$ & -0.48 & $<0.001$ \\
\hline Muscle fiber section mean area, $\mu \mathrm{m}^{2}$ & 1,101 & $2,920.51$ & $-183.93 \pm 67.46$ & -0.24 & $<0.01$ \\
\hline LM area/muscle fiber area, $\times 10^{3}$ & 1,101 & $1,958.74$ & $357.60 \pm 49.79$ & 0.62 & $<0.001$ \\
\hline $\mathrm{pH}$ & 1,114 & 5.61 & $-0.004 \pm 0.006$ & -0.05 & 0.52 \\
\hline Muscle lightness, $\mathrm{L}^{*}$ & 1,114 & 34.75 & $2.05 \pm 0.30$ & 0.57 & $<0.001$ \\
\hline Shear force, $\mathrm{N} / \mathrm{cm}^{2}$ & 1,114 & 38.09 & $-0.73 \pm 0.64$ & -0.10 & 0.25 \\
\hline Tenderness score $^{4}$ & 1,113 & 62.42 & $2.13 \pm 0.69$ & 0.27 & $<0.01$ \\
\hline Juiciness score ${ }^{4}$ & 1,113 & 59.96 & $0.49 \pm 0.45$ & 0.09 & 0.28 \\
\hline Flavor score $^{4}$ & 1,113 & 55.33 & $-0.96 \pm 0.21$ & -0.21 & 0.02 \\
\hline
\end{tabular}

${ }^{1} \mathrm{RSD}=$ root mean square error of the basic model that includes only the fixed effect of the contemporary groups.

${ }^{2}$ Scale of 0 to 4 , where 1 is no difficulty, 2 is easy pull, 3 is hard pull, and 4 is caesarian section.

${ }^{3}$ Scale of 1 to 15 , where 1 is extremely lean and 15 is extremely fat.

${ }^{4}$ Scale of 1 to 100 , where 1 is extremely tough, dry, or weak and 100 is extremely tender, juicy, or intense. 
Table 4. Substitution effect of the normal allele by the Q204X myostatin allele in each of the 13 families of heterozygous Charolais sires for carcass yield and muscle score, with SE, divided by the phenotypic SD (residual $\mathrm{SD}^{1}$ ) and the corresponding $P$-value

\begin{tabular}{|c|c|c|c|c|c|c|}
\hline \multirow[b]{2}{*}{ Sire } & \multicolumn{3}{|c|}{ Carcass yield } & \multicolumn{3}{|c|}{ Muscle score } \\
\hline & $\mathrm{a} \pm \mathrm{SE}$ & $\mathrm{a} / \mathrm{RSD}$ & $P$-value & $\mathrm{a} \pm \mathrm{SE}$ & $\mathrm{a} / \mathrm{RSD}$ & $P$-value \\
\hline 1 & $1.04 \pm 0.86$ & 0.63 & 0.23 & $1.63 \pm 0.81$ & 1.13 & 0.04 \\
\hline 2 & $1.21 \pm 1.00$ & 0.73 & 0.23 & $2.85 \pm 0.94$ & 1.97 & $<0.01$ \\
\hline 3 & $1.23 \pm 0.79$ & 0.75 & 0.12 & $2.59 \pm 0.74$ & 1.79 & $<0.001$ \\
\hline 4 & $1.26 \pm 0.75$ & 0.77 & 0.09 & $0.38 \pm 0.70$ & 0.27 & 0.58 \\
\hline 5 & $1.43 \pm 0.64$ & 0.87 & 0.03 & $1.91 \pm 0.60$ & 1.31 & $<0.01$ \\
\hline 6 & $1.83 \pm 0.76$ & 1.11 & 0.02 & $0.91 \pm 0.71$ & 0.63 & 0.20 \\
\hline 7 & $1.93 \pm 0.69$ & 1.17 & $<0.01$ & $0.75 \pm 0.65$ & 0.52 & 0.24 \\
\hline 8 & $1.95 \pm 0.79$ & 1.18 & 0.01 & $2.30 \pm 0.74$ & 1.59 & $<0.01$ \\
\hline 9 & $2.51 \pm 0.77$ & 1.52 & $<0.01$ & $2.92 \pm 0.71$ & 2.01 & $<0.01$ \\
\hline 10 & $2.56 \pm 0.79$ & 1.55 & $<0.01$ & $1.66 \pm 0.74$ & 1.14 & 0.03 \\
\hline 11 & $2.62 \pm 0.75$ & 1.59 & $<0.001$ & $0.99 \pm 0.70$ & 0.68 & 0.16 \\
\hline 12 & $2.76 \pm 0.64$ & 1.68 & $<0.001$ & $1.89 \pm 0.60$ & 1.30 & $<0.001$ \\
\hline 13 & $2.92 \pm 0.77$ & 1.77 & $<0.001$ & $1.19 \pm 0.72$ & 0.82 & 0.10 \\
\hline
\end{tabular}

observed. The LT muscle of young heterozygous bulls contained less intramuscular lipid $(-0.56 \mathrm{RSD})$ and less insoluble collagen $(-0.48 \mathrm{RSD})$. All these carcass and muscle characteristics were different $(P<0.001)$. Significant differences in histology were also observed $(P<0.01)$. The heterozygotes had thinner muscle fibers $(-0.24 \mathrm{RSD})$ and a greater ratio of rib eye area to fiber area $(+0.62 \mathrm{RSD})$.

No meat quality information was discarded, first because no $\mathrm{pH}$ above 6.0 was found (a clue that animals were slaughtered without stress), in accordance with care transport and slaughter conditions (Mounier et al., 2006), and second because the monitored decline in temperature always followed a normal curve compatible with the absence of cold shortening. The $\mathrm{pH}$ in the LT muscle of heterozygotes was not different from homozygous-normal animals. The LT muscle was markedly lighter $(+0.57$ RSD), however. Although no difference in meat texture was observed when studied via Warner-Bratzler shear force $(-0.10 \mathrm{RSD}, P=$ $0.25)$, moderate differences in sensory tenderness could be detected by the test panel in favor of heterozygotes $(+0.27 \mathrm{RSD}, P<0.01)$. The panelists also detected a slightly lower flavor in heterozygotes $(-0.21 \mathrm{RSD}, P=$ 0.02 ), and no differences in juiciness.

\section{Within-Sire Substitution Effects of the Inactive Q204X Allele on the Carcass Yield and Muscle Score of Charolais Young Bulls}

In each of the 13 families of heterozygous Charolais sires, the parent origin of the Q204X allele could be determined unequivocally in $75 \%$ of the heterozygous calves because most of the dams were genotyped. For carcass yield and muscle score, the substitution effects within sire families (estimated with the second model) were significant $(P<0.001)$. The heterozygous calves that received the inactive allele from their sires had consistently greater carcass yields $(+0.6$ to $+1.8 \mathrm{RSD})$ and muscle scores $(+0.2$ to +2.0 RSD) than their half sibs that received the normal allele (Table 4). The within-sire substitution effects averaged 1.17 RSD for both traits.

\section{DISCUSSION}

The study of allelic frequencies showed that Q204X and nt821 occurred at a very small frequency in the Limousin and Blonde d'Aquitaine breeds. Previous studies of the myostatin polymorphism in the Limousin breed showed that this breed is characterized by an increased frequency of the F94L allele (Grobet et al., 1998; Dunner et al., 2003). This F94L mutation was not investigated in the present study, first because this mutation was thought to be almost fixed in the Limousin breed and absent in the 2 other breeds, and second because Grobet et al. (1998) predicted that the F94L mutation did not interfere drastically with the activity of the myostatin protein. However, this latter assumption was negated by the results of Esmailizadeh et al. (2008), Lines et al. (2009), and Alexander et al. (2009), who showed a significant effect of the F94L mutation. In the present study, even if the association between the beef value of the Limousin cattle and the F94L genotypes could not be studied, the presence of 1 copy of a disruptive mysotatin allele (Q204X or nt821) was shown to increase the beef value of these animals drastically, despite the small frequency of the allele. The 2 mutations, Q204X and nt821, certainly appeared in this breed as a consequence of the extension of the breed by absorbing local populations. Because of the adverse effects on fitness and maternal traits, the French Lim- 
ousin breed association decided to eradicate both mutations (Marc Gambarotto, France Limousin Selection, Boisseuil, France, personal communication).

The situation in the Blonde d'Aquitaine breed is different because Grobet et al. (1998) and Dunner et al. (2003) found that the majority of animals had no mutation in the myostatin gene. In the present study, the effect of a single copy of the Q204X and nt821 disruptive mutations appeared to be less in this breed as compared with the Charolais and Limousin breeds. The power to detect effects in Blonde d'Aquitaine was small because of the low mutated allele frequency, so the number of animals may be too small to accurately estimate an effect as small as $0.5 \mathrm{RSD}$. To detect a difference of 0.5 phenotypic SD between normal homozygous and young heterozygous bulls with $\mathrm{f}$ (frequency of the mutated allele) $=1 \%$, a power of $90 \%$, and a $P$-value of $5 \%$, we should have more than fourfold the number of Blonde d'Aquitaine animals genotyped in our program (Whitley and Ball, 2002); hence, we cannot draw conclusions on the actual effect of the mutated allele in the Blonde d'Aquitaine breed.

Because of the increased frequency of the mutation of the myostatin gene in the Charolais breed, we studied the effect of the inactive allele, Q204X, more thoroughly in this breed. Our results showed that young heterozygous bulls had more muscled $(+1.17$ RSD for carcass yield, +1.01 RSD for muscle score, and +0.65 RSD for rib eye area) and leaner $(-0.57$ RSD for internal fat and $-0.84 \mathrm{RSD}$ for rib fat) carcasses than homozygous animals. The same results were obtained within sire families for carcass yield and muscle score (1.1 RSD on average), although the limited sample size led to less precise estimates (from 0.27 to 2.01 RSD). These within-family results showed that the effect of the myostatin mutated allele did not depend on the family structure, as it ought to for a causal mutation. These results follow the pattern that was reported previously (Casas et al., 1998) with the Belgian Blue and Piedmontese inactive alleles in heterozygous animals. In that study, the mutated allele inherited from presumed heterozygous sires was followed by a set of 5 microsatellites. The authors showed that a single copy of the $\mathrm{mh}$ allele $(\mathrm{mh}=$ mutated myostatin allele) increased the retail product yield and the rib eye area $(+1.60$ and +1.35 RSD, respectively) and decreased the yield grade, fat thickness, and estimated percentage of $\mathrm{KPH}$ $(-1.42,-0.84$, and $-0.86 \mathrm{RSD}$, respectively). Casas et al. (2004) studied the effect of the inactive nt821 allele in a crossed Belgian Blue-British breed (Angus and Hereford) population. They reported that the effects of 2 copies of the mutated allele were generally threefold the effects of a single copy. The individuals inheriting 1 copy of the inactive allele had a greater HCW, retail product yield, and LM area (between $1 / 3$ and 2 RSD) and had decreased fat yield and fat weight (approximately -1 RSD) compared with the homozygous-normal animals. Wiener et al. (2002) reported significant effects of a single nt821 allele on the muscle score and fat depth of heterozygous animals in the South Devon breed. These effects were one-third of the effect of 2 copies. They were less but were consistent with most of the previous studies (between $1 / 7$ and $1 / 3 \mathrm{RSD}$ ). In the same way, the effects of nt821 on carcass conformation, found by Gill et al. (2008) in a Aberdeen Anguscross population, were small (approximately $+1 / 2 \mathrm{RSD}$ of the conformation class grade, LM area, and carcass weight). Moreover, they found no difference between heterozygous and homozygous-normal animals for fat traits, but the small frequency of the nt821 allele clearly suggests that the effects were difficult to estimate in this population.

Concerning muscle composition, we estimated a large difference in intramuscular fat content between heterozygous and normal calves ( -1 RSD), similarly to other studies for the marbling score (Casas et al., 1998, 2004). Heterozygous animals had less collagen content than normal homozygous animals $(-0.48 \mathrm{RSD})$. This finding is consistent with the results of Uytterhaegen et al. (1994). They showed that intramuscular collagen content of LT muscle was significantly reduced by $40 \%$ in double-muscled Belgian Blue-White bulls compared with normal-muscled animals. Ngapo et al. (2002) had the same result in the semitendinosus and the gluteobiceps muscles, but they found no significant difference in intramuscular collagen between normal and heterozygous Belgian Blue bulls. We also showed a greater number of LT muscle fibers (+0.62 RSD) in heterozygous animals. In the study by Wegner et al. (2000), the authors reported that the muscle fiber number of semitendinosus muscle from doubled-muscled young bulls was on average approximately twice that of semitendinosus muscle from German Angus, Galloway, and HolsteinFriesian bulls.

Regarding meat quality, this study indicated that the LT of young heterozygous bulls was more tender than that of homozygous animals according to the trained panelists $(+0.27 \mathrm{RSD})$. This better tenderness can be a consequence of a reduced collagen content and a smaller mean area of the muscle fiber section $(-0.24 \mathrm{RSD})$ because both characteristics have been shown to be related to muscle tenderness (Renand et al., 2001). The mh allele had no significant effect on Warner-Bratzler shear force but the effect was negative ( -0.10 RSD), which is consistent with a more tender meat. The results for tenderness in other studies are divergent. Bailey et al. (1982) reported a more tender meat (LT) in double-muscled Charolais young bulls compared with non-double-muscled animals, as determined by a taste panel with confirmation by a measure of compression force. Wheeler et al. (2001b) measured the tenderness of 4 muscles as determined by a sensory panel and a measure of the ease of myofibrillar fragmentation in a population of Piedmontese crossbred steers and heifers. For the 2 traits, they found that all muscles were more tender in $\mathrm{mh} /+$ than $+/+$ (between $1 / 5$ and $1 \mathrm{RSD}$ ), and they estimated no difference between the tenderness of $\mathrm{mh} /+$ and $\mathrm{mh} / \mathrm{mh}$ except in the biceps femoris. 
Several studies reported no effect of the myostatin gene on meat tenderness. Ménissier (1982a) did not find a difference in Warner-Bratzler shear force of LT between progeny of double-muscled Charolais sires and progeny of non-doubled-muscled Charolais sires. Similarly, Casas et al. (1998) concluded that a single copy of the mh allele had no effect on LM Warner-Bratzler shear force in crossbred animals. In the same way, the results of Gill et al. (2008) did not support a difference in meat tenderness (measured by a tenderometer) between normal homozygous and heterozygous Angus-cross animals for the nt821 mutation. Short et al. (2002) had the same conclusion after comparing Warner-Bratzler shear force of meat from $+/+, \mathrm{mh} /+$, and $\mathrm{mh} / \mathrm{mh}$ Piedmontese calves. Uytterhaegen et al. (1994) found the opposite result; they showed that the meat (LT muscle) of normal-muscled Belgian Blue-White bulls was more tender than that of doubled-muscled Belgian Blue-White bulls by a measure of Warner-Bratzler shear force.

Regarding meat flavor and juiciness, we reported in this study that the meat of heterozygous animals had less flavor and the same juiciness compared with the meat of young homozygous-normal bulls. In light of the previous results, this decreased meat flavor could be a consequence of the reduced intramuscular lipid content. The results of Wheeler et al. (2001b) showed less flavor intensity for the $\mathrm{mh} / \mathrm{mh}$ genotype than for the $+/+$ genotype $(-1 / 4 \mathrm{RSD})$, but they did not report a difference between the $\mathrm{mh} /+$ and $+/+$ genotypes in the Piedmontese breed. According to the same reference, juiciness ratings were less for the $\mathrm{mh} /+$ genotype than for the $+/+$ genotype (except in biceps femoris) and were less for the $\mathrm{mh} / \mathrm{mh}$ genotype than for the $\mathrm{mh} /+$ or $+/+$ genotype. However, Wheeler et al. (1996) found that the LM of $\mathrm{F}_{1} \mathrm{mh} /+$ Piedmontese had less flavor intensity than that of Hereford $\times$ Angus. In addition, Wheeler et al. (2001a) reported that the LM of $\mathrm{F}_{1}$ $\mathrm{mh} /+$ Belgian Blue and $\mathrm{F}_{1} \mathrm{mh} /+$ Piedmontese had less juiciness than that of Hereford $\times$ Angus, but there was no difference in flavor intensity ratings.

We also showed in this paper that heterozygous animals were slightly heavier at birth than homozygous-normal calves, which is consistent with the results reported in other studies (Casas et al., 1998, 1999, 2004; Short et al., 2002; Wiener et al., 2009) in which heterozygous calves were heavier at birth than homozygous-normal calves (+1/4 RSD on average). As a consequence of the increase in birth weight, calving difficulties also increased significantly, as observed by Casas et al. (1999), Short et al. (2002), and Wiener et al. (2009). However, Short et al. (2002) pointed out that calving difficulty was increased in Piedmontese heifers as 1 and 2 copies of the inactive allele were added in the calf, but they found no effect with cows. Therefore, knowledge of the mh genotype of the mating bulls is required to avoid procreating heterozygous calves when mating heifers.

In conclusion, because of adverse effects on dystocia and fitness, double-muscled animals are not desired by producers despite their greater beef value. On the ba- sis of our findings, producing young bulls with 1 copy of the inactive myostatin allele can improve carcass yield and muscle score in the Charolais and Limousin breeds. Moreover, in the Charolais breed, we showed that heterozygous animals had better carcass and meat qualities without a marked increase in birth weight. This slight increase in the birth weight of the calf could have a prejudicial effect on calving ease if the dam is a heifer. Consequently, controlling the inheritance of the myostatin allele by genetic tests could be a solution to have better beef performance if the appropriate mating strategy is applied to adult cows.

\section{LITERATURE CITED}

Alexander, L. J., L. A. Kuehn, T. P. L. Smith, L. K. Matukumalli, B. Mote, J. E. Koltes, J. Reecy, T. W. Geary, D. C. Rule, and M. D. MacNeil. 2009. A Limousin specific myostatin allele affects longissimus muscle area and fatty acid profiles in a Wagyu-Limousin $\mathrm{F}_{2}$ population. J. Anim. Sci. 87:1576-1581.

Arthur, P. F. 1995. Double muscling in cattle: A review. Aust. J. Agric. Res. 46:1493-1515.

Bailey, A. J., M. B. Enser, E. Dransfield, D. J. Restall, and N. C. Avery. 1982. Muscle and adipose tissue from normal and double muscled cattle: Collagen types, muscle fibre diameter, fat cell size and fatty acid composition and organoleptic properties. Pages 178-204 in Muscle Hypertrophy of Genetic Origin and Its Use to Improve Beef Production. J. W. B. King and F. Ménissier, ed. Martinus Nijhoff Publishers, Leiden, the Netherlands.

Bergman, I., and R. Loxley. 1963. Two improved and simplified methods for the spectrometric determination of hydroxyproline. Anal. Chem. 35:1961-1965.

Bonnet, M., and J. Kopp. 1984. Dosage du collagène dans les tissues conjonctifs, la viande et les produits carnés. Cah. Tech. INRA $5: 19-30$.

Casas, E., G. L. Bennett, T. P. L. Smith, and L. V. Cundiff. 2004. Association of myostatin on early calf mortality, growth, and carcass composition traits in crossbred cattle. J. Anim. Sci. 82:2913-2918.

Casas, E., J. W. Keele, S. C. Fahrenkrug, T. P. Smith, L. V. Cundiff, and R. T. Stone. 1999. Quantitative analysis of birth, weaning, and yearling weights and calving difficulty in Piedmontese crossbreds segregating an inactive myostatin allele. J. Anim. Sci. 77:1686-1692.

Casas, E., J. W. Keele, S. D. Shackelford, M. Koohmaraie, T. S. Sonstegard, T. P. L. Smith, S. M. Knappes, and R. T. Stone. 1998. Association of the muscle hypertrophy locus with carcass traits in beef cattle. J. Anim. Sci. 76:468-473.

Charlier, C., W. Coppieters, F. Farnir, L. Grobet, P. L. Leroy, C. Michaux, M. Mni, A. Schwers, P. Vanmanshoven, R. Hanset, and M. Georges. 1995. The mh gene causing double-muscling in cattle maps to bovine Chromosome 2. Mamm. Genome 6:788-792.

De Boer, H., B. L. Dumont, R. W. Pomeroy, and J. H. Weniger. 1974. Manual on E.A.A.P. reference methods for the assessment of carcass characteristics in cattle. Livest. Prod. Sci. 1:151-164.

Dunner, S., C. Charlier, F. Farnir, B. Brouwers, J. Canon, and M. Georges. 1997. Towards interbreed IBD fine mapping of the mh locus: Double-muscling in the Asturiana de los Valles breed involves the same locus as in the Belgium Blue cattle breed. Mamm. Genome 8:430-435.

Dunner, S., M. E. Miranda, Y. Amigues, J. Canon, M. Georges, R. Hanset, J. Williams, and F. Ménissier. 2003. Haplotype diversity of the myostatin gene among beef cattle breeds. Genet. Sel. Evol. 35:103-118.

Esmailizadeh, A. K., C. D. K. Bottema, G. S. Sellick, A. P. Verbyla, C. A. Morris, N. G. Cullen, and W. S. Pitchford. 2008. Effects 
of the myostatin F94L substitution on beef traits. J. Anim. Sci. 86:1038-1046.

Gill, J. L., S. C. Bishop, C. McCorquodale, J. L. Williams, and P. Wiener. 2008. Associations between the 11-pb deletion in the myostatin gene and carcass quality in Angus-sired cattle. Anim. Genet. 40:97-100.

Grobet, L., L. J. R. Martin, D. Poncelet, D. Pirottin, B. Brouwers, J. Riquet, A. Schoeberlein, S. Dunner, F. Ménissier, J. Massabanda, R. Fries, R. Hanset, and M. Georges. 1997. A deletion in the bovine myostatin gene causes the double-muscled phenotype in cattle. Nat. Genet. 17:71-74.

Grobet, L., D. Poncelet, L. J. Royo, B. Brouwers, D. Pirottin, C. Michaux, F. Ménissier, M. Zanotti, S. Dunner, and M. Georges. 1998. Molecular definition of an allelic series of mutations disrupting the myostatin function and causing double-muscling in cattle. Mamm. Genome 9:210-213.

Kambadur, R., M. Sharma, T. P. L. Smith, and J. J. Bass. 1997. Mutations in the myostatin $(G D F 8)$ in double-muscled Belgian Blue and Piedmontese cattle. Genome Res. 7:910-915.

Lines, D. S., W. S. Pitchford, Z. A. Kruk, and C. D. K. Bottema. 2009. Limousin myostatin F94L variant affects semitendinosus tenderness. Meat Sci. 81:126-131.

McPherron, A. C., and S. J. Lee. 1997. Double muscling in cattle due to mutations in the myostatin gene. Proc. Natl. Acad. Sci. USA 94:12457-12461.

Ménissier, F. 1982a. Advantages of using muscled sires in crossbreeding and the selection of a specialised double muscled sire line in France. Pages 480-536 in Muscle Hypertrophy of Genetic Origin and Its Use to Improve Beef Production. J. W. B. King and F. Ménissier, ed. Martinus Nijhoff Publishers, Leiden, the Netherlands.

Ménissier, F. 1982b. General survey of the effect of double muscling on cattle performance. Pages 23-53 in Muscle Hypertrophy of Genetic Origin and Its Use to Improve Beef Production. J. W. B. King and F. Ménissier, ed. Martinus Nijhoff Publishers, Leiden, the Netherlands.

Ménissier, F. 1982c. Present state of knowledge about the genetic determination of muscular hypertrophy or the double muscled trait in cattle. Pages 387-428 in Muscle Hypertrophy of Genetic Origin and Its Use to Improve Beef Production. J. W. B. King and F. Ménissier, ed. Martinus Nijhoff Plubishers, Leiden, the Netherlands.

Mounier, L., H. Dubroeucq, S. Andanson, and I. Veissier. 2006. Variations in meat $\mathrm{pH}$ of beef bulls in relation to conditions of transfer to slaughter and previous history of the animals. J. Anim. Sci. 84:1567-1576.
Ngapo, T. M., P. Berge, J. Culioli, E. Dransfield, S. De Smet, and E. Claeys. 2002. Perimysial collagen crosslinking and meat tenderness in Belgian Blue double-muscled cattle. Meat Sci. 61:91-102.

Renand, G., B. Picard, C. Touraille, P. Berge, and J. Lepetit. 2001. Relationships between muscle characteristics and meat quality traits of young Charolais bulls. Meat Sci. 59:49-60.

Short, R. E., M. D. MacNeil, M. D. Grosz, D. E. Gerrard, and E. E. Grings. 2002. Pleiotropic effects in Hereford, Limousin and Piedmontese $\mathrm{F}_{2}$ crossbred calves of genes controlling muscularity including the Piedmontese myostatin allele. J. Anim. Sci. 80:1-11.

Smith, T. P. L., N. L. Lopez-Corrales, S. M. Kappes, and T. S. Sonstegard. 1997. Myostatin maps to the interval containing the bovine mh locus. Mamm. Genome 8:742-744.

Uytterhaegen, L., E. Claeys, D. Demeyer, M. Lippens, L. O. Fiems, C. Y. Boucqué, G. Van de Voorde, and A. Bastiaens. 1994. Effects of double-muscling on carcass quality, beef tenderness and myofibrillar protein degradation in Belgian Blue White bulls. Meat Sci. 38:255-267.

Wegner, J., E. Albrecht, I. Fiedler, F. Teuscher, H. J. Papstein, and K. Ender. 2000. Growth- and breed-related changes of muscle fiber characteristics in cattle. J. Anim. Sci. 78:1485-1496.

Wheeler, T. L., L. V. Cundiff, R. M. Koch, and J. D. Crouse. 1996. Characterization of biological types of cattle (Cycle IV): Carcass traits and longissimus palatability. J. Anim. Sci. 74:10231035.

Wheeler, T. L., L. V. Cundiff, S. D. Shackelford, and M. Koohmaraie. 2001a. Characterization of biological types of cattle (Cycle V): Carcass traits and longissimus palatability. J. Anim. Sci. 79:1209-1222.

Wheeler, T. L., S. D. Shackelford, E. Casas, L. V. Cundiff, and M. Koohmaraie. 2001b. The effects of Piedmontese inheritance and myostatin genotype on the palatability of longissimus thoracis, gluteus medius, semimembranosus and biceps femoris. J. Anim. Sci. 79:3069-3074.

Whitley, E., and J. Ball. 2002. Statistics review 4: Sample size calculations. Crit. Care 6:335-341.

Wiener, P., J. A. Smith, A. M. Lewis, J. A. Woolliams, and J. L. Williams. 2002. Muscle-related traits in cattle: The role of the myostatin gene in the South Devon breed. Genet. Sel. Evol. 34:221-232.

Wiener, P., J. A. Woolliams, A. Frank-Lawale, M. Ryan, R. I. Richardson, G. R. Nute, J. D. Wood, D. Homer, and J. L. Williams. 2009. The effects of a mutation in the myostatin gene on meat and carcass quality. Meat Sci. 83:127-134. 
References

Citations

This article cites 31 articles, 13 of which you can access for free at: http://www.journalofanimalscience.org/content/88/2/446\#BIBL

This article has been cited by 3 HighWire-hosted articles:

http://www.journalofanimalscience.org/content/88/2/446\#otherarticles 